\title{
31. PETROLOGY OF VOLCANIC ROCKS RECOVERED ON LEG 18
}

\author{
Norman S. MacLeod, U. S. Geological Survey, Menlo Park, California \\ and \\ Richard M. Pratt, NOAA, Rockville, Maryland
}

\section{INTRODUCTION}

Volcanic rocks were recovered at five of the sites drilled on Leg 18. Preliminary shipboard petrologic studies of cored samples were augmented by onshore petrographic and petrochemical studies. At Sites 172, 173, and 178 acoustic basement was sampled. The basement consists of basalt at Sites 172 and 178 and of andesite at Site 173. At Site 177 a basalt sill was encountered in the middle of a submarine fan section. Basalt from Site 179 is similar to rocks from the adjacent Giacomini Seamount.

Major element chemical analyses of the cored rocks listed in Tables 1 to 5, were made using analytical methods described in U.S.G.S. Bulletin 1144A supplemented by atomic absorption. Trace element contents of the rocks, determined by spectrographic analysis, are also reported in Tables 1 to 5 and have an overall accuracy of \pm 15 percent except near the limits of detection where only one significant figure is shown.

\section{DESCRIPTION OF VOLCANIC ROCKS}

\section{Site $\mathbf{1 7 2}$}

The volcanic rock recovered from Site 172 consists of fragments of glassy to finely crystalline basalt and palagonite up to about $5 \mathrm{~mm}$ in long dimension; small fragments (less than $5 \mathrm{~mm}$ ) of phillipsite were also recovered with the basalt.

The glassy basalt fragments contain plagioclase, augite, and olivine microphenocrysts that grade serially to microlites, and sideromelane glass, palagonite, or a very fine-grained hemicrystalline matrix. The proportion of the microphenocrysts and microlites is virtually identical in all glassy fragments thin sectioned. The mode, based on 4500 points counted, is: plagioclase, $4.0 \%$; augite, $4.4 \%$; olivine, $0.3 \%$; and matrix, $91.3 \%$. The plagioclase crystals have a maximum size of about 0.5 by $0.25 \mathrm{~mm}$, but most are 0.2 by $0.05 \mathrm{~mm}$. Augite crystals are typically about $0.1 \mathrm{~mm}$ in diameter and range to $0.2 \mathrm{~mm}$. Olivine crystals, mostly altered to a brown birefringent clay mineral, are about $0.05 \mathrm{~mm}$ in length. Plagioclase and augite, and to a lesser extent olivine, also occur as glomerophenocrysts that have a maximum diameter of $1 \mathrm{~mm}$. The augite and plagioclase crystals contain minute inclusions of glass; small gas bubbles occur in this glass.

Plagioclase crystals show slight progressive zoning and have minimum $\mathrm{Nx}$ of 1.560 and maximum $\mathrm{Nz}$ of 1.575 indicating a range in composition of about $\mathrm{An}^{64}$ on crystal rims to $\mathrm{An}^{75}$ in cores of larger crystals. Augite crystals show a small range in extinction angle and are also progressively zoned. The augite has Ny about 1.695 and $2 \mathrm{~V}$ about $48^{\circ}$, indicating a composition of approximately
$\mathrm{Mg}_{38} \mathrm{Fe}_{22} \mathrm{Ca}_{40}$. Only a few olivine crystals have survived alteration and their composition was not determinable by optical methods. The sideromelane glass that makes up the bulk of these fragments is clear and light brown in color and has an index of refraction of 1.600 to 1.603 . It contains a few vesicles, up to $0.15 \mathrm{~mm}$ in diameter, that are lined fibropalagonite. Some cracks in sideromelane are lined by fibro- or gelpalagonite, as are the rims of many sideromelane fragments. In other fragments the original sideromelane has been altered entirely to palagonite.

The microcrystalline matrix of some fragments is composed of variolitic sheaves of plagioclase, pyroxene, opaque iron-titanium oxides and hydroxides, and glass or its clay alteration products; olivine may have been present, but if it was it has been entirely altered to clay minerals. Most crystals in the matrix are less than $0.01 \mathrm{~mm}$ wide but sheaves of plagioclase and pyroxene are as much as $0.1 \mathrm{~mm}$ long. The microcrystalline matrix is too fine grained for mineral proportions to be determined.

The glassy to very finely crystalline nature of the fragments indicates rapid quenching by water. Most likely the fragments are from a tuff-breccia or pillow flow. The phillipsite fragments may have formed a cement in the breccia or between pillows.

Pieces of relatively fresh basalt from the core were hand picked for chemical analysis. As many of the pieces had small discontinuous rims of palagonite, they were ground to less than $0.3 \mathrm{~mm}$ and the palagonite and any enclosed crystals in palagonite were removed by flotation in bromoform. The bromoform density was adjusted to less than that of plagioclase so that the bulk composition of the fragments was not significantly altered other than by removal of palagonite and enclosed crystals. It was not feasible to remove all palagonite without grinding the sample to a finer size. Further grinding would have resulted in separation of enclosed crystals from the palagonite, thereby changing the ratio of crystals to glass, palagonite, or fine-grained matrix. The chemical analysis and norm of fragments of glassy basalt from Site 172 are shown in Table 1a. The original analysis is listed along with this analysis recalculated water-free to $100 \%$. The norm was calculated using the original $\mathrm{Fe}_{2} \mathrm{O}_{3} / \mathrm{FeO}$ and also using a ratio of $1 / 9$; the $\mathrm{Fe}_{2} \mathrm{O}_{3} / \mathrm{FeO}$ of the magma from which the rock was derived most likely was intermediate between these two values. By both calculations the rock is quartz normative and on the basis of normative classification, the rock is a tholeiitic basalt. Compared with average oceanic ridge tholeiitic basalts and tholeiitic olivine basalts from the Juan de Fuca and Gorda ridges, it has somewhat higher $\mathrm{SiO}_{2}$, total iron oxide, and $\mathrm{K}_{2} \mathrm{O}$ and lower content of $\mathrm{MgO}$ and $\mathrm{CaO}$. With the exception of $\mathrm{SiO}_{2}$ and $\mathrm{MgO}$, however, 
TABLE 1a

Chemical Analysis and Norm of Basalt from Site 172

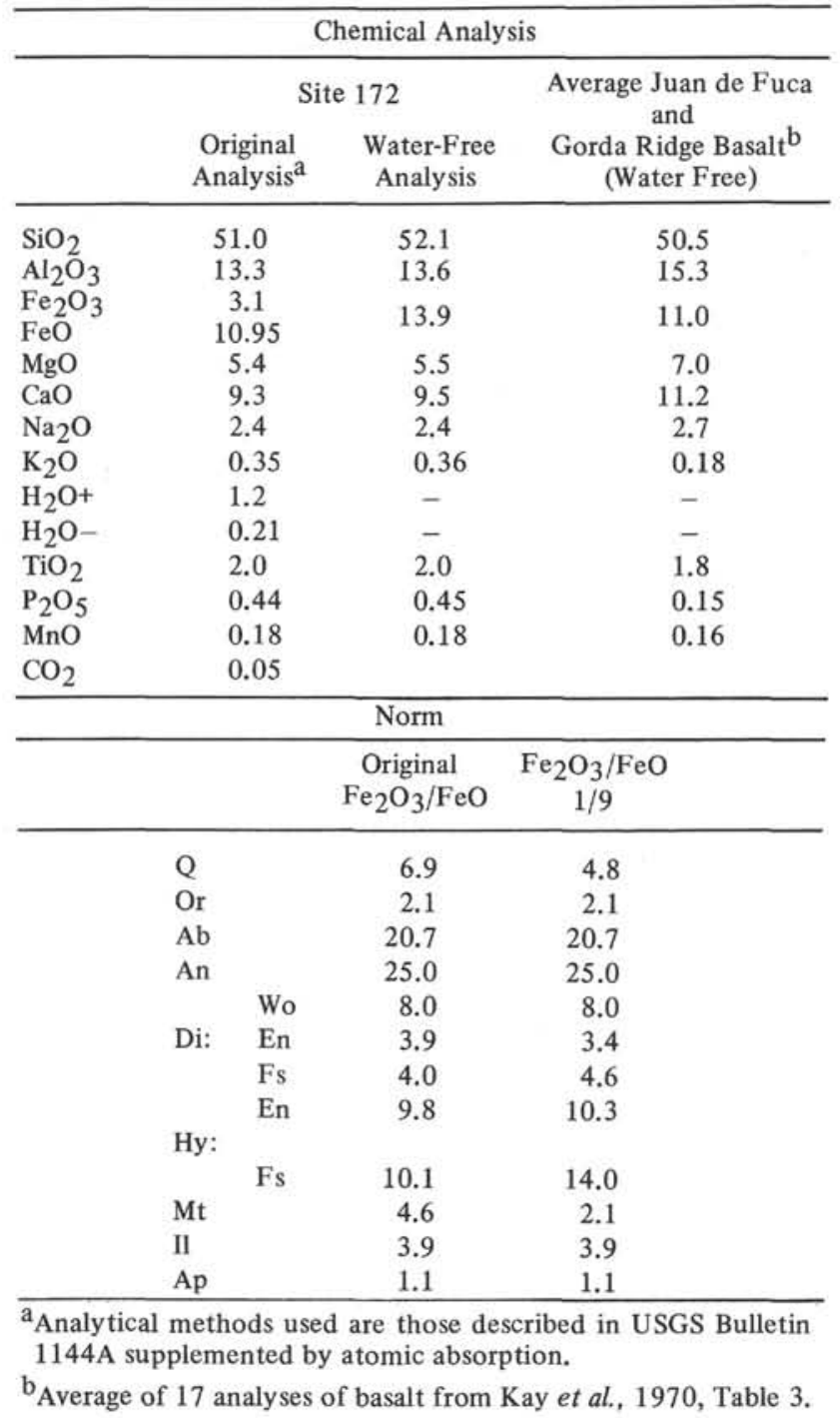

all the oxides fall within the range in percent of the individual oxides for 17 analyzed basalts from these two spreading centers. Other analyzed abyssal tholeiites from both the Atlantic and Pacific oceans also contain slightly less $\mathrm{SiO}_{2}$ and more $\mathrm{MgO}$ than the Site 172 basalt. Most oceanic ridge basalts are olivine normative; those that are quartz normative generally contain less $\mathrm{Q}$ than does the tholeiitic basalt from Site 172 . The $\mathrm{Di} / \mathrm{Di}+\mathrm{Hy}$ ratio (0.4-0.44) of the Site 172 basalt is also somewhat less than that for basalt from the Juan de Fuca and Gorda ridges. The slightly higher $\mathrm{K}_{2} \mathrm{O}$ content at Site 172 compared with most ridge basalts is particularly significant and may indicate that it is not of ridge origin. Only 2 of 17 analyzed basalts from Juan de Fuca and Gorda ridges contain more than $0.22 \mathrm{~K}_{2} \mathrm{O}$ (see Kay et al., 1970, Table 3); basalt from Site 172 has $0.35 \% \mathrm{~K}_{2} \mathrm{O}$. In respect to many of the oxides the chemical composition of basalt from Site 172 appears to fall between values typical of tholeiitic basalts from spreading ridges and tholeiitic basalts from some seamounts and oceanic islands. The basalt may be the produce of eruption of slightly differentiated basalt away from the ridge crest.

The trace element abundances of basalt from Site 172 (Table $1 \mathrm{~b}$ ) are generally similar to those reported by Engel et al. (1965) for oceanic tholeiitic basalt except that the Site 172 basalt contains greater than normal $\mathrm{Zr}$ and $\mathrm{Y}$ and less $\mathrm{Cr}$ and Ni. Except in these four elements the Site 172 basalt differs from average alkali basalt as reported by Engel et al. (1965). The content of $\mathrm{Sr}(130 \mathrm{ppm})$ and the $\mathrm{Ba} / \mathrm{Sr}$ ratio (0.18) of the basalt are similar to values reported by Gast (1968, Fig. 5) and Kay et al. (1970 Fig. 11 and Table 4) to be typical of abyssal basalts. The $\mathrm{Ni} / \mathrm{Cr}(0.33)$ is also similar to oceanic basalt according to the data of Kay et al. (1970, Fig. 11).

\section{Site 173}

Volcanic rock was recovered in both the extended barrel and core catcher of Cores 37 and 38 at Site 173. The samples are mostly small fragments less than $2 \mathrm{~cm}$ across; the largest fragment is $5 \mathrm{~cm}$ in largest dimension. Fragments of hard rock were incorporated in the sediment of Cores 32,35 , and 36 , but their cherty lithology and rounded shapes suggest they are clasts from the sediment column or from thin lithified beds. The volcanic fragments from the bottom of the hole are glassy to aphanitic and contain small feldspar phenocrysts. The fragments are gray, purple, or green and many are extensively altered. Rims of many fragments are altered, and small veins filled with opaline material occur in others. All fragments contain numerous vesicles. Although the chips are too small to show the gross structure of the rock body, it seems likely, considering the amount of glassy and very fine-grained chips, that they are from a subaqueous breccia or pillow-breccia flow.

TABLE 1b

Trace Element Abundances (Spectrographic Analysis, ppm) of Site 172 Basalt Compared to Average Composition of Oceanic Tholeiitic Basalt and Alkali Basalt

\begin{tabular}{lrcc}
\hline & $\begin{array}{c}\text { Site } \\
172^{1}\end{array}$ & $\begin{array}{c}\text { Average Oceanic } \\
\text { Tholeiitic Basalt } \mathrm{b}\end{array}$ & $\begin{array}{c}\text { Average } \\
\text { Alkali Basaltb }\end{array}$ \\
\hline $\mathrm{Ba}$ & 24 & 14 & 498 \\
$\mathrm{Co}$ & 40 & 32 & 25 \\
$\mathrm{Cr}$ & 150 & 297 & 67 \\
$\mathrm{Cu}$ & 69 & 77 & 36 \\
$\mathrm{Ga}$ & 17 & 17 & 22 \\
$\mathrm{La}$ & $\mathrm{N} 30$ & $<80$ & $90 ?$ \\
$\mathrm{Nb}$ & $\mathrm{N} 15$ & $<30$ & 72 \\
$\mathrm{Ni}$ & 50 & 97 & 51 \\
$\mathrm{Sc}$ & 62 & 61 & 26 \\
$\mathrm{Sr}$ & 130 & 130 & 815 \\
$\mathrm{~V}$ & 350 & 292 & 252 \\
$\mathrm{Y}$ & 100 & 43 & 54 \\
$\mathrm{Yb}$ & 12 & 5 & 4 \\
$\mathrm{Zr}$ & 320 & 95 & 333 \\
\hline
\end{tabular}

aSite 172 analysis results are reported to two significant figures and have an overall accuracy of $\pm 15 \%$ except that they are less accurate near the limits of detection where only one digit is intended. $\mathrm{N}=$ Not detected at value shown.

bEngel et al., 1965, Table 2. 
In thin section the volcanic rock is porphyritic-seriate with phenocrysts, microphenocrysts, and microlites of plagioclase and altered olivine that are set in very light brown glass or in a hemicrystalline matrix. Half of the thin sections also contain hypersthene phenocrysts or xenocrysts. Several sections contain quartz xenocrysts about 1 $\mathrm{mm}$ in length that have well-developed cliopyroxene reaction rims. Vesicles lined by phillipsite(?) and another zeolite, as well as by clay minerals, constitute 1 to $5 \%$ of the rock and are most abundant in rocks with a high glass content. Vesicles in thin section are as much as $1.3 \mathrm{~mm}$ across but typically are 0.5 to $1 \mathrm{~mm}$ across. In hand specimen, some crystal-lined vesicles several $\mathrm{mm}$ across were observed.

The plagioclase crystals range serially from phenocrysts $5-1 / 2 \mathrm{~mm}$ by $2-1 / 2 \mathrm{~mm}$ down to microlites less than 0.1 $\mathrm{mm}$ long. Phenocrysts are euhedral to subround in shape; microlites are euhedral. Larger phenocrysts have inclusions of glass or finely crystalline material in their cores that appear to reflect an early partial resorption and a few have apatite crystal inclusions. Some small clear glass(?) inclusions in the plagioclase contain minute gas bubbles. The plagioclase phenocrysts show both progressive and oscillatory zoning whereas microphenocrysts and microlites show only progressive zoning. Plagioclase separated from one sample has $\mathrm{Nx}($ minimum $)=1.550$ and $\mathrm{Nz}$ (maximum) $=1.567$ indicating a range composition of about $\mathrm{An}_{40}$ to $\mathrm{An}_{61}$; phenocrysts are labradorite and groundmass plagioclase is andesine. Smaller plagioclase crystals also occur as geomeroporphyritic clots with olivine. A few $1 / 2$ to $1 \mathrm{~mm}$ wide plagioclase "clots" consist of numerous individual crystals interlocked with a hornfelsic texture. Some of these clots contain garnet(?) inclusions and are probably xenoliths.

Pseudomorphs of former olivine phenocrysts up to $1 \mathrm{~mm}$ wide and microlites as small as $0.1 \mathrm{~mm}$ are common. They are composed of green to tan phyllosilicate minerals but many display the characteristic olivine crystal shape. Because of the alteration the modal olivine determined by point counting ( 3 to $6 \%$ ) is only approximate. Minute opaque minerals occur on or near the crystal margins of former olivine but appear to be an alteration product rather than a reaction rim; no pyroxene reaction rims were observed.

Hypersthene phenocrysts or xenocrysts occur in half the samples studied. They commonly are irregular in shape and some crystals are deeply embayed and have irregular patches of glass developed in their cores as a result of resorption. Some hypersthene crystals have poorly developed exsolution lamellae and patches. The hypersthene has $2 \mathrm{~V}$ of about $60^{\circ}$, indicating a composition of about En65.

The phenocrysts, microphenocrysts, microlites, and xenocrysts are set in a matrix that ranges from glassy to hemicrystalline. The isotropic glassy matrix is clear light tan. Alteration to clay minerals (fibropalagonite) has occurred along cracks and halos of minute crystallites radiate outward from most phenocrysts and microlites. The matrix of other sections ranges from glass with abundant minute pyroxene crystallites that produce an almost opaque tachylite, to rocks with 0.05 to $0.2 \mathrm{~mm}$ long pyroxene and plagioclase crystals with interstitial greenish clay and brown glass dusted by crystallites. The pyroxene in the matrix appears to be entirely augite and it contains numerous opaque mineral inclusions. Some of the green clay mineral in the interstices may fill small amygdules, most of it, however, probably developed in place during deuteric alteration.

The abundance of phenocrysts, xenocrysts, and xenoliths in the rock, the oscillatory zoning of the phenocrysts, and evidence of partial resorption indicate a complex history before the lava underwent final solidification. The clots of hornfelsic plagioclase, the quartz xenocrysts, and perhaps the hypersthene crystals may have been torn from wall rocks as the magma ascended to the surface. The abundance of glass and particularly the development of an entirely glass matrix in some samples indicates subaqueous eruption.

Modal analyses of four samples of varying degree of crystallinity are given in Table 2a. Chemical and trace element analyses of the most crystalline rock are shown in Tables $2 \mathrm{~b}$ and $2 \mathrm{c}$ where they are compared to analyses of various rock types.

Both the original analysis (Core 38 ) and this analysis recalculated water-free to $100 \%$ are given in Table $2 \mathrm{~b}$. The original analysis gives $6.3 \% \mathrm{H}_{2} \mathrm{O}$; this and, the high oxidation state of iron, indicates the high degree of alteration of the rock. The norm was calculated with the original $\mathrm{Fe}_{2} \mathrm{O}_{3} / \mathrm{FeO}$ and a ratio of $1 / 9$; the original oxidation state of the iron probably was between these two extremes. The rock is quartz-normative and its normative plagioclase is $\mathrm{An}_{49}$, essentially at the commonly accepted $\mathrm{An}_{50}$ division between basalt and andesite.

The average composition of andesite according to Nockolds (1954) is also listed in Table $2 \mathrm{~b}$. The volcanic rock from Site 173 is very similar in chemical composition to the average andesite. The composition of the volcanic rock from Site 173 is similar to some Tertiary and Quaternary basaltic andesites from the Cascade Range, two of which are listed in Table $2 \mathrm{~b}$ for comparison. The Site 173 andesite differs in composition from typical abyssal basalts and from most rocks of similar $\mathrm{SiO}_{2}$ content from seamounts and oceanic islands which commonly are not quartz normative.

TABLE 2a

Modal Analyses of Andesite from Site 173

\begin{tabular}{lcccc}
\hline \multicolumn{1}{c}{ Sample } & 38B & 37A & 37B & 38A \\
\hline Vesicles and amygdules & 5 & 4 & 3 & 1 \\
Plagioclase & 9 & $11^{1 / 2}$ & 16 & 27 \\
Augite & - & trace & - & 11 \\
$\begin{array}{l}\text { Hypersthene } \\
\text { Olivine }\end{array}$ & 6 & 6 & 3 & 4 \\
$\begin{array}{l}\text { Glass, microcrystalline } \\
\text { matrix and alteration } \\
\text { products of indeterminate } \\
\text { minerals }\end{array}$ & $799^{1 / 2}$ & 78 & 78 & 57 \\
\hline
\end{tabular}


TABLE 2b

Chemical Analysis and Norm of Volcanic Rock from Site 173 (Core 38)

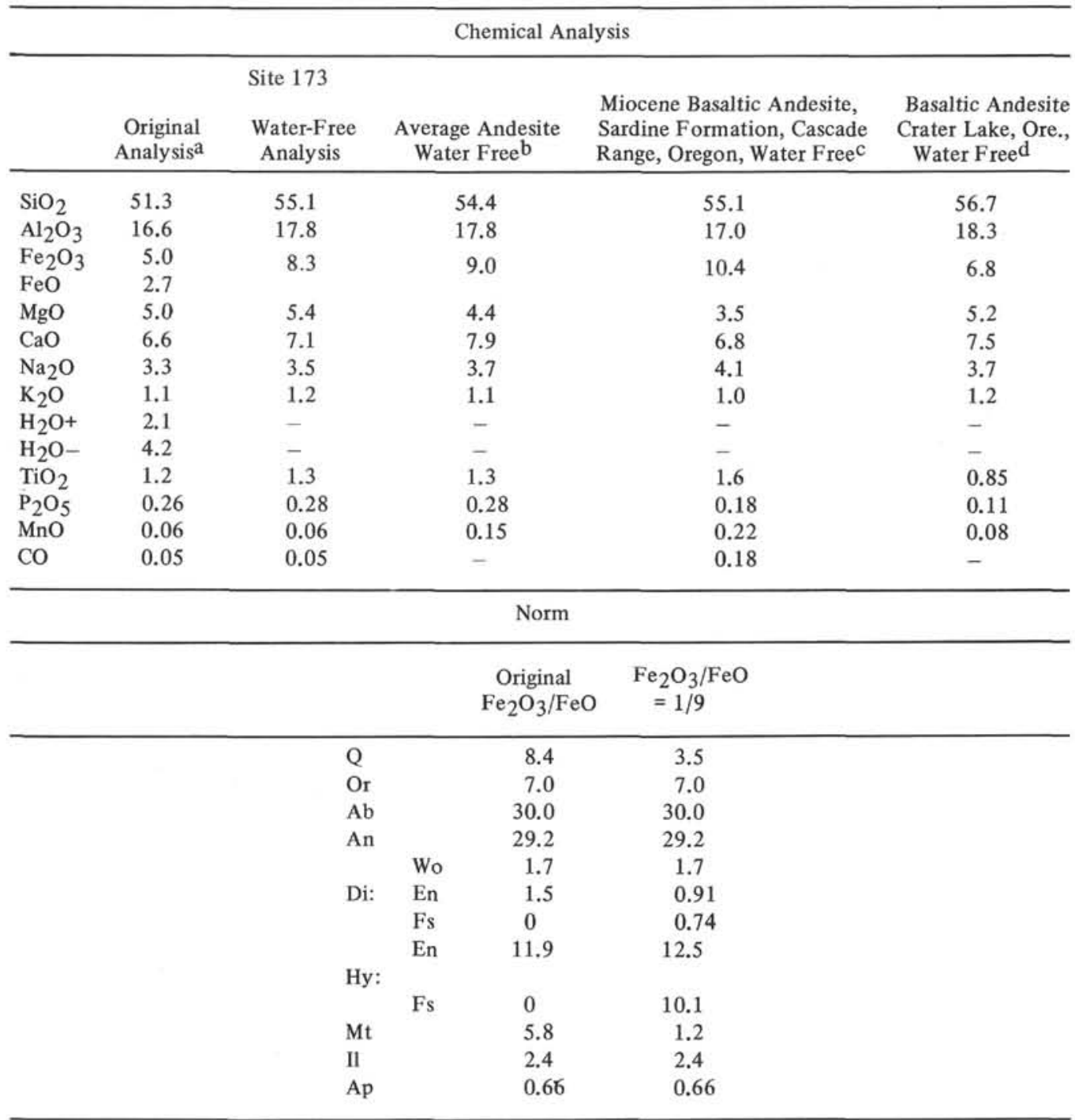

\footnotetext{
${ }^{\mathrm{a}}$ Analytical methods used are those described in USGS Bulletin 1144A supplemented by atomic absorption.

brom Nockolds, 1954.

${ }^{C}$ From Peck et al., 1964, Table 7, Col. 8.

$\mathrm{d}_{\text {From Williams, 1942, Anal. } 10 .}$
}

Comparison of trace element abundances of the analyzed andesite from Site 173 with average abundances of oceanic tholeiitic basalt, alkali basalt, andesite, and low silica andesite. Table 20 shows that relative to oceanic basalt the andesite from Site 173 contains significantly greater quantities of the large cations, $\mathrm{Ba}, \mathrm{Sr}$, and $\mathrm{Zr}$, and lesser quantities of the "ferromagnesian" elements $\mathrm{Co}, \mathrm{Cr}$, $\mathrm{Cu}, \mathrm{Ni}, \mathrm{Sc}$, and $\mathrm{V}$, and similar or lesser quantities of the rare earths, $\mathrm{Y}$ and $\mathrm{Yb}$. The $\mathrm{Ba} / \mathrm{Sr}$ ratio (1.3) of the Site 173 andesite is much greater than that of oceanic basalt reported by Gast (1968, Fig. 5) which ranges approximately from 0.01 to 0.24 . Also the $\mathrm{Ni} / \mathrm{Cr}$ ratio $(0.05)$ is much less than Gast (1968, Fig. 6) reports to be typical of oceanic tholeiites $(0.25$ to about 0.7$)$. The Site 173 andesite also differs markedly in content of some of the trace elements, particularly $\mathrm{Cr}, \mathrm{Nb}, \mathrm{Ni}$, and $\mathrm{Sr}$, from average alkali basalt as listed by Engel et al. (1965). Although in respect to content of many of the trace elements, the Site 173 andesite is similar to average andesite and low silica andesite of Taylor (1969); it contains significantly greater $\mathrm{Ba}, \mathrm{Cr}$, and $\mathrm{Y}$, and less $\mathrm{Cu}$ and $\mathrm{Zr}$.

\section{Site 177}

Hard rock was penetrated in a drilled interval at 381.5 meters. Drilling was stopped to take Core 24, which recovered $190 \mathrm{~cm}$ of hard, dark greenish gray to black basalt. Core 25 penetrated $160 \mathrm{~cm}$ of basalt and then broke through into sediment again. The drilling penetration record indicates that the total thickness of basalt in the section is about 5 meters. The seismic record suggests it is contained in a fault zone. 
TABLE 2c

Trace Element Abundances (Spectrographic Analysis, ppm) in Site 173 Andesite Compared to Average Composition of Other Rocks

\begin{tabular}{lrrrrr}
\hline & Site & $\begin{array}{c}\text { Average } \\
\text { Oceanic } \\
\text { Tholeiitic } \\
\text { Basalt }\end{array}$ & $\begin{array}{c}\text { Average } \\
\text { Alkali } \\
\text { Basalt }\end{array}$ & $\begin{array}{c}\text { Average } \\
\text { Andesitec }\end{array}$ & $\begin{array}{c}\text { Average } \\
\text { Low-Si } \\
\text { Andesitec }\end{array}$ \\
\hline $\mathrm{Ba}$ & 560 & 14 & 498 & 270 & 200 \\
$\mathrm{Co}$ & 23 & 32 & 25 & 24 & 28 \\
$\mathrm{Cr}$ & 190 & 297 & 67 & 56 & 85 \\
$\mathrm{Cu}$ & 20 & 77 & 36 & 54 & 60 \\
$\mathrm{Ga}$ & 15 & 17 & 22 & 16 & 13 \\
$\mathrm{La}$ & $\mathrm{N} 30$ & $<80$ & $90 ?$ & 12 & 10 \\
$\mathrm{Nb}$ & $\mathrm{N} 15$ & $<30$ & 72 & 4 & 4 \\
$\mathrm{Ni}$ & 15 & 97 & 51 & 18 & 28 \\
$\mathrm{Sc}$ & 32 & 61 & 26 & 30 & 11 \\
$\mathrm{Sr}$ & 420 & 130 & 815 & 385 & 430 \\
$\mathrm{~V}$ & 160 & 292 & 252 & 175 & 200 \\
$\mathrm{Y}$ & 36 & 43 & 54 & 21 & 22 \\
$\mathrm{Yb}$ & 4 & 5 & 4 & 2 & 2 \\
$\mathrm{Zr}$ & 200 & 95 & 333 & 110 & 92 \\
\hline
\end{tabular}

${ }^{a}$ Site 173 analysis results are reported to two significant figures and have an overall accuracy of $+15 \%$ except that they are less accurate near the limits of detection where only one digit is intended. $\mathrm{N}=$ Not detected at value shown.

${ }^{b}$ Engel et al, 1965, Table 2.

cTaylor, 1969, Tables 1-6.

The apparent massive nature of the basalt body suggests it is probably a dike or sill; however, an extrusive origin cannot be discounted. The underlying sediment and the hard carbonate-cemented sediment below the contact here slickensided fractures that might be associated with intrusion, but the fracturing and vein-filling in the basalt itself and slickensides found in sediments above the body indicate post-solidification fracturing. The overall tectonic setting of the drill site suggests that the basalt body may be in fault contact with the adjacent sediments.

The basalt core consists of approximately 35 hard, rounded blocks 5 to $15 \mathrm{~cm}$ in length. The cored rock is various shades of gray and green and has several fractures and vein-filled fractures at various angles to the length of the core. The cracks are filled with soft greenish chlorite and aragonite and have slick green surfaces.

The lower contact of the basalt and mudstone is shown in one sample. The mudstone is slightly baked at the contact to produce greater than normal induration but shows no apparent increase in grain size nor development of incipient porphyroblasts. Considering the thickness of the basalt body (about $5 \mathrm{~m}$ ), no marked contact metamorphic effects would be expected. Calcite fills fractures in the indurated mudstone at and near the contact and also occurs in the basalt with aragonite along small fractures in the interior of the body.

Within 2 to $3 \mathrm{~cm}$ of the contact the basalt contains scattered clay-filled amygdules, typically $0.5 \mathrm{~mm}$ across. The basalt is microporphyritic-seriate and contains a few plagioclase phenocrysts 1 to $2 \mathrm{~mm}$ long as well as plagioclase microphenocyrsts that range frod a maximum of 0.2 by $1 \mathrm{~mm}$ serially down to microlites that are 0.02 by
$0.2 \mathrm{~mm}$. The microlites commonly have forked terminations and curved shape. Olivine microphenocrysts that are entirely altered to clay minerals occur with the plagioclase and are typically $0.2 \mathrm{~mm}$ wide. The plagioclase and olivine microphenocrysts tend to occur in irregular clots. Both minerals contain small $(0.01$ to $0.05 \mathrm{~mm})$ reddish brown spinel octahedra. The microphenocrysts and microlites are set in a very fine-grained hemicrystalline matrix composed of pyroxene, plagioclase, opaque minerals, and clay minerals. Most of the clays probably have replaced former glass. The pyroxene in the matrix commonly occurs as groups of parallel-oriented, irregularly shaped elongate crystals. The grain size of the matrix increases towards the center of the body.

In the interior of the body, the texture becomes subophitic and the plagioclase has a variable grain size that is typically 0.1 to $0.5 \mathrm{~mm}$; several $2 \mathrm{~mm}$ plagioclase phenocrysts were observed. Samples from near the center of the body contain about $45 \%$ plagioclase, 30 to $35 \%$ augite, and $1 / 4 \%$ spinel in addition to very fine-grained pyroxene, opaque minerals, and clay minerals that occur sporadically in the interstices between larger mineral grains. Some clay appears to be pseudomorphic after olivine, but determination of the proportion of original olivine is subjective because similar clays occur also in the matrix as an alteration product of glass. Pyroxene is fresh, plagioclase is dusted in places with alteration products.

Plagioclase shows progressive zoning and cores of larger crystals range in composition from about $\mathrm{An}_{65}$ to $\mathrm{An}_{68}$; smaller crystals and outermost rims of larger crystals are more sodic. Pyroxene crystals appear to be generally uniform in composition except adjacent to the fine-grained matrix or where they are zoned to a darker brown color, probably indicating an increase in $\mathrm{Fe}$ and (or) $\mathrm{Ti}$ content. Most of the pyroxene has $\mathrm{Ny}=1.687-1.691$ and $2 \mathrm{~V}=51^{\circ}$, indicating a composition of about $\mathrm{Ca}_{42} \mathrm{Mg}_{43} \mathrm{Fe}_{15}$. The opaque minerals in the finely crystalline residue were not studied in polished section but appear in thin section to be mainly magnetite ${ }_{s s}$ with lesser ilmenite ${ }_{s s}$. Rare, minute red hematite plates were also noted. A few clay and calcitefilled amygdules about $0.3 \mathrm{~mm}$ across occur in the basalt. Modal analysis of four samples from the basalt body based on 1000 or more points per sample are shown in Table $3 \mathrm{a}$.

A chemical analysis and morm of the basalt from Hole 177A (sample $24-140 \mathrm{~cm}$ ) are shown in Table $3 \mathrm{~b}$. The

TABLE 3a

Modal Analyses of Basalt from Site 177

\begin{tabular}{lclcc}
\hline Sample & $25-116$ & $24-10$ & $24-114$ & $24-140$ \\
\hline Plagioclase $191 / 2$ & 40 & $461 / 2$ & 43 \\
Olivine $^{\mathrm{a}}$ & $71 \frac{1}{2}$ & 10 & $81 / 2$ & 8 \\
Spinel & $1 / 4$ & $1 / 4$ & $1 / 4$ & $1 / 4$ \\
Pyroxene & & 35 & $291 / 2$ & 34 \\
Matrix b & 72 & $141 / 2$ & $151 / 4$ & $141 / 2$ \\
Amygdules & $1 / 4$ & $1 / 4$ & - & $1 / 4$ \\
\hline
\end{tabular}

${ }^{\mathrm{a} E n t i r e l y}$ replaced by clay minerals, proportion shown is approximate.

${ }^{b}$ Very fine-grained opaque minerals, pyroxene, and clay minerals (after glass?). 
TABLE 3b

Chemical Analysis and Norm of Basalt from Site 177

Chemical Analysis

\begin{tabular}{lccc}
\hline & \multicolumn{2}{c}{ Site 177} & \\
Original & Water-Free \\
Analysis & Analysis & $\begin{array}{c}\text { Average Juan de Fuca and } \\
\text { Gorda Ridge Basalt } \\
\text { (Water Free) }\end{array}$ \\
\hline $\mathrm{SiO}_{2}$ & 48.7 & 50.6 & 50.5 \\
$\mathrm{Al}_{2} \mathrm{O}_{3}$ & 16.8 & 17.5 & 15.3 \\
$\mathrm{Fe}_{2} \mathrm{O}_{3}$ & 3.0 & 3.1 & 11.0 \\
$\mathrm{FeO}$ & 4.8 & 5.0 & 7.0 \\
$\mathrm{MgO}$ & 7.4 & 7.7 & 11.2 \\
$\mathrm{CaO}$ & 11.8 & 12.3 & 2.7 \\
$\mathrm{Na} 2 \mathrm{O}$ & 2.3 & 2.4 & 0.18 \\
$\mathrm{~K}_{2} \mathrm{O}$ & 0.03 & 0.03 & - \\
$\mathrm{H}_{2} \mathrm{O}+$ & 1.3 & - & 1.8 \\
$\mathrm{H}_{2} \mathrm{O}-$ & 2.2 & - & 0.15 \\
$\mathrm{TiO}_{2}$ & 1.1 & 1.1 & 0.16 \\
$\mathrm{P}_{2} \mathrm{O}_{5}$ & 0.14 & 0.14 & - \\
$\mathrm{MnO}$ & 0.11 & 0.11 & \\
$\mathrm{CO}_{2}$ & 0.05 & 0.12 & \\
\hline
\end{tabular}

\begin{tabular}{lccc}
\hline \multicolumn{4}{c}{ Norm } \\
\hline & & $\begin{array}{c}\text { Original } \\
\mathrm{Fe}_{2} \mathrm{O}_{3} / \mathrm{FeO}\end{array}$ & $\begin{array}{c}\mathrm{Fe}_{2} \mathrm{O}_{3} / \mathrm{FeO} \\
1 / 9\end{array}$ \\
\hline $\mathrm{Q}$ & & 2.0 & - \\
$\mathrm{Or}$ & & 0.18 & 0.18 \\
$\mathrm{Ab}$ & & 20.2 & 20.2 \\
$\mathrm{An}$ & & 36.8 & 36.8 \\
& Wo & 9.7 & 9.7 \\
$\mathrm{Di}:$ & $\mathrm{En}$ & 7.0 & 5.8 \\
& $\mathrm{Fs}$ & 1.8 & 3.3 \\
$\mathrm{Hy}:$ & $\mathrm{En}$ & 12.2 & 11.5 \\
& $\mathrm{Fs}$ & 3.1 & 6.6 \\
$\mathrm{Fo}$ & & & 1.3 \\
$\mathrm{Fa}$ & & & 0.81 \\
$\mathrm{Mt}$ & & 4.5 & 1.2 \\
II & & 2.2 & 2.2 \\
$\mathrm{Ap}$ & & 0.32 & 0.32 \\
\hline
\end{tabular}

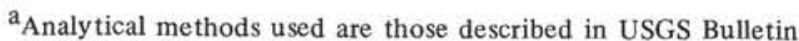
$1144 \mathrm{~A}$ supplemented by atomic absorption.

${ }^{b}$ Average of 17 analyses of basalt from Kay et al, 1970, Table 3.

analysis is shown both as the original and recalculated water-free to $100 \%$ and the norm is shown calculated on the original analysis as well as with $\mathrm{Fe}_{2} \mathrm{O}_{3} / \mathrm{FeO}$ of $1 / 9$. Depending on the original oxidation state of the iron which probably lay between the observed $\mathrm{Fe}_{2} \mathrm{O}_{3} / \mathrm{FeO}$ of $3 / 4.8$ and an arbitrarily assigned value of $1 / 9$, the rock is normatively a tholeiitic basalt or tholeiitic olivine basalt. The alteration of the 8 to $10 \%$ former olivine in the rock probably accounts largely for the relatively high ferric iron content, and the former unaltered rock was most likely an olivine normative tholeiitic olivine basalt. Its composition is very similar to that of ridge basalts dredged from the nearby Juan de Fuca Ridge and the Gorda Ridge, whose average composition of which is also shown in the table. The content of $\mathrm{Al}_{2} \mathrm{O}_{3}$ and total iron in the Site 177 basalt differs somewhat from the average ridge basalt, but a few of the seventeen analyses used to compile the average have similar $\mathrm{Al}_{2} \mathrm{O}_{3}$ and total iron contents. Particularly significant is the low $\mathrm{K}_{2} \mathrm{O}$ content of the Site 177 basalt $(0.03)$, as low $\mathrm{K}_{2} \mathrm{O}$ is of oceanic ridge basalts.

Trace element abundances of the tholeiitic basalt from Site 177 are compared in Table $3 \mathrm{c}$ with average oceanic tholeiitic basalt and alkalic basalt, and also with average tholeiitic basalt of Kilauea, Hawaii. With respect to most trace elements, the Site 177 basalt is most similar to average oceanic tholeiitic basalt, although it does contain somewhat greater $\mathrm{Co}, \mathrm{Cr}, \mathrm{Ni}$, and $\mathrm{Sr}$ than average oceanic tholeiite of Engel et al. (1965, Table 2). Other workers (e.g. Gast, 1968), however, report contents of these four elements in oceanic tholeiitic basalt similar to those of the basalt of Site 177. The $\mathrm{Ba} / \mathrm{Sr}$ ratio $(0.075), \mathrm{Ni} / \mathrm{Cr}$ ratio $(0.4)$, and the content of $\mathrm{Ba}, \mathrm{Sr}, \mathrm{Ni}$, and $\mathrm{Cr}$ are typical of oceanic tholeiitic basalt according to the data of Gast (1968, Fig. 5). Trace element abundances of tholeiitic basalt from the nearby Juan de Fuca Ridge are also similar to Site 177 basalt according to the data of Kay et al. (1970). Site 177 basalt differs in content of many trace elements from average alkalic basalt and average Kilauea tholeiitic basalt. Particularly notable are the much lower contents in the Site 177 basalt of $\mathrm{Ba}, \mathrm{La}, \mathrm{Nb}, \mathrm{Sr}$, and $\mathrm{Zr}$.

\section{Site 178}

Hole 178 penetrated 17 meters of basalt at the bottom and recovered $40 \mathrm{~cm}$ of hard-rock core. The depth to the basalt corresponds closely to depth to acoustic basement in the reflection records.

TABLE 3c

Trace Element Abundances (Spectrographic Analysis, ppm) in Site 177 Tholeiitic Basalt Compared to Average Composition of Oceanic Tholeiitic Basalt and Alkali Basalt

\begin{tabular}{lcccc}
\hline & $\begin{array}{c}\text { Site } 177^{\mathrm{a}} \\
\text { Tholeiitic } \\
\text { Basalt }\end{array}$ & $\begin{array}{c}\text { Average } \\
\text { Oceanic } \\
\text { Tholeitic } \\
\text { Basaltb }\end{array}$ & $\begin{array}{c}\text { Average } \\
\text { Alkalic } \\
\text { Basalt }\end{array}$ & $\begin{array}{c}\text { Average } \\
\text { Kilauea, Hawaii } \\
\text { Tholeiitic } \\
\text { Basaltc }\end{array}$ \\
\hline $\mathrm{Ba}$ & 15 & 14 & 498 & 184 \\
$\mathrm{Co}$ & 54 & 32 & 25 & 46 \\
$\mathrm{Cr}$ & 380 & 297 & 67 & 252 \\
$\mathrm{Cu}$ & 91 & 77 & 36 & 207 \\
$\mathrm{Ga}$ & 15 & 17 & 22 & 18 \\
$\mathrm{La}$ & $\mathrm{N} 30$ & $<80$ & $90 ?$ & $\mathrm{NR}$ \\
$\mathrm{Nb}$ & $\mathrm{N} 15$ & $<30$ & 72 & NR \\
$\mathrm{Ni}$ & 150 & 97 & 51 & 164 \\
$\mathrm{Sc}$ & 55 & 61 & 26 & 34 \\
$\mathrm{Sr}$ & 200 & 130 & 815 & 652 \\
$\mathrm{~V}$ & 300 & 292 & 252 & 339 \\
$\mathrm{Y}$ & 42 & 43 & 54 & 50 \\
$\mathrm{Yb}$ & 4 & 5 & 4 & NR \\
$\mathrm{Zr}$ & 74 & 95 & 333 & 202 \\
\hline
\end{tabular}

${ }^{\text {a }}$ Site 177 analysis results are reported to two significant figures and have an overall accuracy of $+15 \%$ (except that they are less accurate near the limits of detection where one digit is intended. $\mathrm{N}=$ Not detected at values shown.

${ }^{b}$ Engel et al, 1965, Table 2.

'Prinz, 1967, Table 4. 
In hand specimen, the basalt core is massive and dark gray. Several chilled glassy basalt selvages in the cores may be margins of pillows. Veinlets about $2 \mathrm{~mm}$ wide are common in the basalt. They are filled by calcite and aragonite. In thin section the rock ranges from glass with scattered microphenocrysts of olivine to coarse-grained holocrystalline basalt. Between the two extremes are rocks that show progressive crystallinity and that are particularly notable because of the feathery texture of the quenched olivine.

The finest grained basalt samples are microporphyritic and glassy. They consist of 4 to $10 \%$ olivine microphenocrysts that are irregularly dispersed in a glassy matrix. The glass appears black (tachylite) in thin section, but, in conoscopic light on thin edges of sections, the tachylite can be seen to consist of exceptionally fine-grained variolitic crystalline phases, probably largely pyroxene, olivine, plagioclase, and opaque minerals, in addition to glass. The olivine microphenocrysts are typically 0.1 to $1.5 \mathrm{~mm}$ in longest dimension. Although many are euhedral, others are marked by irregular reentrants filled by tachylite or contain round inclusions of tachylite in their cores. The olivine microphenocrysts contain small dark yellowish brown spinel euhedra. The olivine has $\mathrm{Nx}=1.668, \mathrm{Ny}=1.6885$, and $\mathrm{Nz}=1.708$ indicating a composition of about Fo8 1 . $\mathrm{X}$-ray diffraction patterns also indicate a composition of Fo80-81 according to the method of Hotz and Jackson (1963), but $\mathrm{Fo}_{85}$ according to that of Yoder and Sahama (1957).

With a slight increase in grain size the matrix becomes variolitic and contains pyroxene, olivine, plagioclase, and opaque minerals along with microphenocrysts of olivine similar to those in the glassy rocks. Most groundmass crystals in the finer grained samples are less than $0.4 \mathrm{~mm}$ long and tend to be markedly elongate. Olivine in the groundmass occurs as very elongate crystals typically 0.02 $\times 1 \mathrm{~mm}$, that occur scattered through the matrix. Some of these elongate olivines occur as spearlike projections from equant olivine microphenocrysts; many are developed on microphenocryst terminations parallel to the $\mathrm{C}$ direction. Many of the small elongate olivine crystals occur as discontinuous chains of grains; others have very irregular borders. Similar olivine crystals in tholeiitic olivine basalt from the mid-Atlantic Ridge are described by Aumento (1968). The elongate olivine in the basalt is most likely a product of relatively rapid quenching. Similar olivine habit has been reported in laboratory-quenched melts of approximately basaltic composition. The olivine microphenocrysts and elongate olivine are extensively altered to clay minerals, serpentine(?), and hydrous iron oxides, or to calcite. Plagioclase in the variolitic matrix also is partly altered.

A continuous change is shown from microporphyritic basalt with a very fine-grained variolitic matrix to rocks with much coarser grain size. The basalt is composed of plagioclase, pyroxene, olivine, opaque minerals, and trace amounts of brown spinel, in addition to abundant clay minerals that replace plagioclase and olivine. Much clay occurs in the interstices and seems to replace former glass. The plagioclase crystals show a large range in grain size; some are as much as $2 \mathrm{~mm}$ long; others are only $0.1 \mathrm{~mm}$. The larger crystals are progressively zoned from $\mathrm{An}_{60}$ to
$\mathrm{An}_{69}$ in crystal cores to about $\mathrm{An}_{55}$ on the rims. Smaller crystals are probably similar in composition to rims of larger crystals. The smaller crystals are in places intergrown with pyroxene in subophitic fashion. The pyroxene commonly occurs as sets of parallel-oriented crystals $0.5 \mathrm{~mm}$ in long dimension or smaller. The pyroxene separated from one sample has $\mathrm{Ny}$ about 1.72 and $2 \mathrm{~V}$ about $53^{\circ}$. The color of the pyroxene ranges from light pinkish brown to brownish lavender and pleochroism and dispersion are noticeable. The color, pleochroism, and dispersion indicate a relatively high $\mathrm{Ti}$ content in the augite. Olivine crystals comprise about $10 \%$ of the coarser rocks and are mostly altered, but a few of the coarsest grained sections had no olivine. Opaque minerals, which based on shape in transmitted light appear to be both ilmenite $_{s s}$ and magnetite ${ }_{s s}$, comprise up to $5 \%$ of the basalt. Modal analyses of typical samples of the basalt based on 1000 or more points per section are shown in Table 4a. Alteration products of minerals were counted with the mineral they replace where determinable.

A chemical analysis and norm of basalt from Site 178 (Core 59 bottom) are shown in Table $4 \mathrm{~b}$. The analysis is shown both as the original and recalculated water- and calcium carbonate-free. Removal of calcium carbonate reduces the $\mathrm{CaO}$ content by only $0.3 \%$ which results in a decrease in normative Wo of $0.6 \%$; both norms shown are calcium carbonate-free. The norm is shown calculated with the analyzed $\mathrm{Fe}_{2} \mathrm{O}_{3} / \mathrm{FeO}$ ratio of $7.3 / 5.9$ and with a ratio of $1 / 9$. The high ferric iron and water content reflect alteration that is shown by thin sections of the rock. Using the 7.3/5.9 iron ratio the rock is quartz normative; however, prior to alteration this ratio was almost certainly much lower, and the rock probably originally had a normative composition more nearly like the strongly olivine normative composition calculated using $\mathrm{Fe}_{2} \mathrm{O}_{3} / \mathrm{FeO}$ of $1 / 9$. The high olivine content in the rock (as much as 14\%) also indicates that the original rock was olivine normative. According to normative classification the Site 178 volcanic rock is a tholeiitic olivine basalt. Compared with an average of oceanic ridge basalts from the Juan de Fuca and Gorda ridges, it contains more total iron, $\mathrm{MgO}$, and $\mathrm{K}_{2} \mathrm{O}$, and less $\mathrm{CaO}$ and $\mathrm{SiO}_{2}$. Several of the basalts from these ridges, however, have similar contents of all but $\mathrm{K}_{2} \mathrm{O}$. The Site 178 basalt differs from these ridge basalts in a manner similar to that of the somewhat more siliceous tholeiitic basalt from

TABLE 4a

Modal Composition of Basalt from Site 178

\begin{tabular}{lcccc}
\hline \multicolumn{1}{c}{ Sample } & 58A & 59D & 59B & 59C \\
\hline Olivine & 2 & 4 & 14 & 12 \\
Pyroxene & - & - & 27 & 27 \\
Plagioclase & - & - & 41 & 44 \\
Brown spinel & Trace & Trace & Trace & Trace \\
$\begin{array}{l}\text { Opaque minerals } \\
\text { Indeterminate minerals }\end{array}$ & -98 & - & 4 & 5 \\
$\begin{array}{l}\text { and (or) fine-grained } \\
\text { or glassy matrix }\end{array}$ & & 96 & 14 & 13 \\
\hline
\end{tabular}


TABLE $4 b$

Chemical Analysis and Norm of Basalt from Site 178 (Core 59,

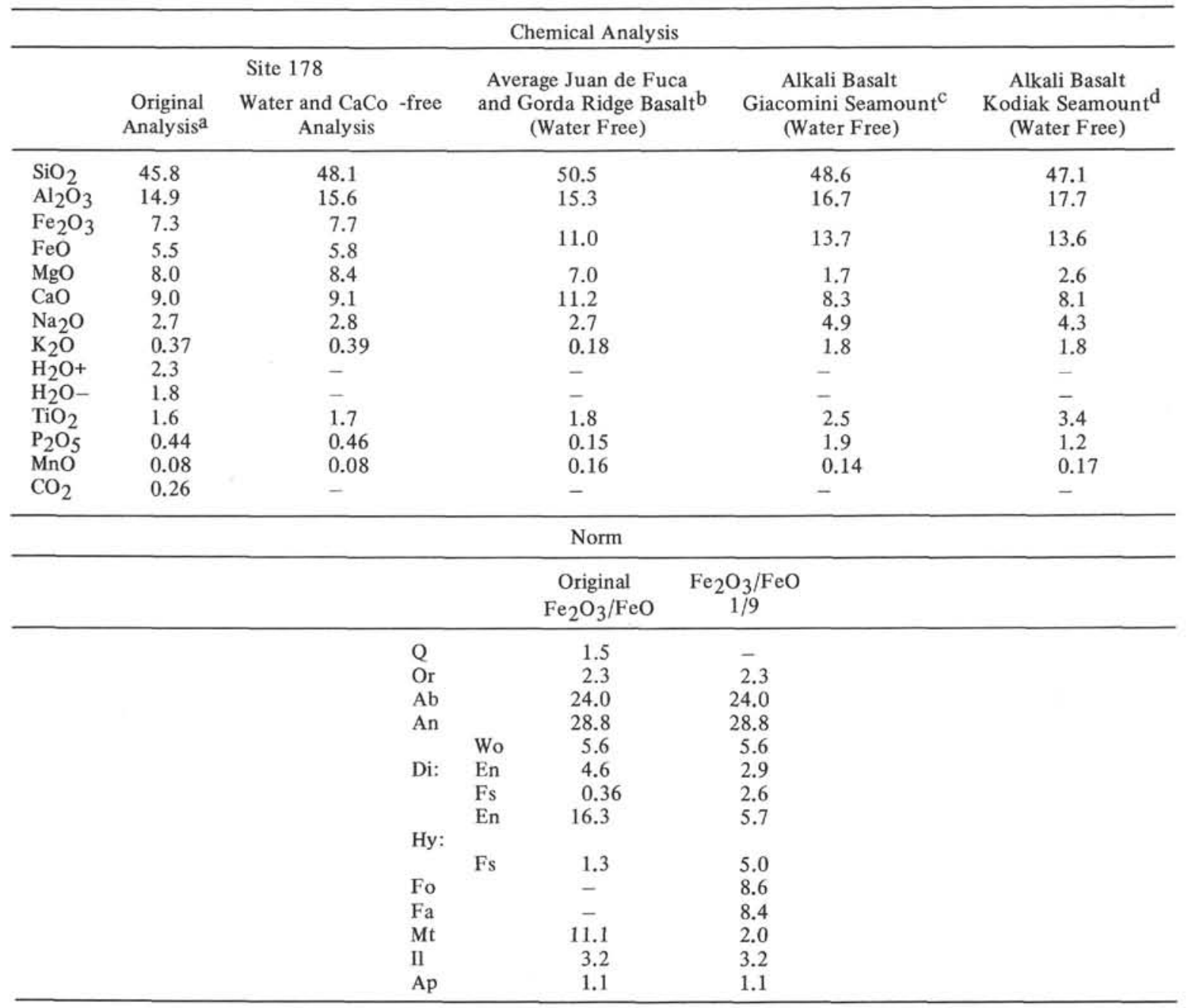

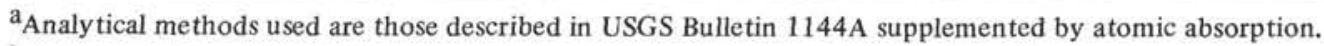

b Average of 17 analyses of basalt from Kay et al, 1970, Table 3.

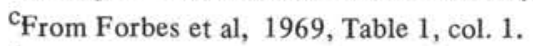

${ }^{\mathrm{d}}$ From Forbes and Hoskin, 1969, Table 1, col. 7.

Site 172. Both of these basalts may have been produced by continued eruption of slightly differentiated basalt away from a ridge crest. Alteration of the Site 178 basalt, however, may have produced some of the observed chemical anomalies (see Hart, 1970). The Site 178 tholeiitic olivine basalt differs in composition from alkalic basalt (hawaiite) and trachyte from the nearby Kodiak and Giacomini seamounts, analyses of which are also shown in Table 4b. Many seamounts and oceanic islands, however, have a veneer of alkalic rocks over tholeiitic basalt that may be similar in composition to Site 178 basalt.

Trace element abundances (ppm) of the basalt from Site 178 are listed in Table 4c, along with those of Engel et al. (1965) for average oceanic tholeiitic basalt and alkali basalt. Site 178 basalt contains more $\mathrm{Ba}, \mathrm{Co}, \mathrm{Ni}$, and $\mathrm{Sr}$ than the average oceanic tholeiitic basalt. Compared with average alkalic basalt, it contains more $\mathrm{Cr}, \mathrm{Cu}, \mathrm{Ni}$, and $\mathrm{Sr}$, and less $\mathrm{Ba}, \mathrm{La}, \mathrm{Nb}$, and $\mathrm{Zr}$. With respect to most of the listed trace elements, it is intermediate in composition between the tholeiitic and alkalic basalt. The high $\mathrm{Ni}, \mathrm{Cr}$, and $\mathrm{Co}$ content may result from the relatively abundant olivine microphenocrysts and their enclosed spinel euhedra which commonly contain relatively abundant amounts of these trace elements. Although the $\mathrm{Ba} / \mathrm{Sr}$ ratio $(0.16)$ is similar to ratios of oceanic tholeiitic basalt (but much less than alkalic basalt) reported by Gast (1968), both $\mathrm{Ba}$ and $\mathrm{Sr}$ are present in much greater quantities than typical of oceanic tholeiitic basalt.

\section{Site 179}

Hole 179 bottomed in volcanic basement or a basalt conglomerate at 109 meters. Core 12 contains one large and three small pieces of weathered brown volcanic rock in the core catcher along with some brown clay. Core 13 recovered only a few angular pebbles or fragments of volcanic rock amongst many other pebbles, and Core 11 
TABLE $4 \mathrm{c}$

Trace Element (Spectrographic Analysis, ppm) of Basalt from Site 178 and the Average Trace Element Content of Oceanic Tholeiitic Basalt and Alkalic Basalt

\begin{tabular}{lccc}
\hline & $\begin{array}{c}\text { Site 178 } \\
\text { Basalt }^{\mathrm{a}}\end{array}$ & $\begin{array}{c}\text { Average Oceanic } \\
\text { Tholeiitic Basalt }^{\mathrm{b}}\end{array}$ & $\begin{array}{c}\text { Average } \\
\text { Alkalic Basalt }\end{array}$ \\
\hline $\mathrm{Ba}$ & 64 & 14 & 498 \\
$\mathrm{Co}$ & 75 & 32 & 25 \\
$\mathrm{Cr}$ & 350 & 297 & 67 \\
$\mathrm{Cu}$ & 63 & 77 & 36 \\
$\mathrm{Ga}$ & 18 & 17 & 22 \\
$\mathrm{La}$ & $\mathrm{N} 30$ & $<80$ & $90 ?$ \\
$\mathrm{Nb}$ & $\mathrm{N} 15$ & $<30$ & 72 \\
$\mathrm{Ni}$ & 290 & 97 & 51 \\
$\mathrm{Sc}$ & 40 & 61 & 26 \\
$\mathrm{Sr}$ & 390 & 130 & 815 \\
$\mathrm{~V}$ & 250 & 292 & 252 \\
$\mathrm{Y}$ & 44 & 43 & 54 \\
$\mathrm{Yb}$ & 3 & 5 & 4 \\
$\mathrm{Zr}$ & 140 & 95 & 333 \\
\hline
\end{tabular}

${ }^{\text {a }}$ Site 178 analysis results are reported to two significant figures and have an overall accuracy of $+15 \%$ except that they are less accurate near the limits of detection where only one digit is intended.

${ }^{b}$ Engel et al., 1965, Table 2.

contained a bed of water-sorted basaltic sand and fine gravel bedded between zeolite-bearing red clay. As much as 0.5 meters of red clay may occur between the basaltic sand and gravel and the bottom of the hole.

The fragments of volcanic rock in Cores 12 and 13 are similar in composition. The rock is strongly weathered and in places has concentric-ringed weathered zones. The rock is very fine grained, equigranular, and hemicrystalline. It contains about 1 to $3 \%$ vesicles, 1 to $2 \mathrm{~mm}$ in diameter, that are lined by a zeolite(?). The fine grain size and alteration make petrographic description difficult. Plagioclase is the principal crystalline phase and comprises as much as $60 \%$ of the more crystalline rocks studied. In the finest grained rocks, however, discrete plagioclase crystals comprise only 10 to $20 \%$, although a considerable amount may be present in the very fine grained or glassy matrix. The plagioclase occurs as flow-aligned microlites that are typically 0.1 to $0.3 \mathrm{~mm}$ long and 0.01 to $0.03 \mathrm{~mm}$ wide; a few crystals are as large as 0.2 by $0.5 \mathrm{~mm}$. The plagioclase has a maximum $\mathrm{Nz}$ of 1.559 and minimum $\mathrm{Nx}$ of less than 1.552 , indicating a composition of about $\mathrm{An}_{46}$ and less.

Plagioclase crystals show progressive zoning; the larger crystals also show oscillatory zoning. Two thin sections contain small quantities (less than $3 \%$ ) of a mafic mineral that is probably olivine but might be hypersthene. This mafic mineral occurs as 0.05 to $0.3 \mathrm{~mm}$ long crystals, mostly altered to clay minerals that are irregularly distributed in the rock.

The matrix between plagioclase laths is composed of altered glass and extremely fine-grained crystalline phases. In thin sections of the coarsest grained rocks, altered glass is milor and the crystalline phases are sufficiently coarse to identify augite, plagioclase, alkali(?) feldspar, apatite, a zeolite(?), and goethite or hematite along with alteration products. The augite occurs as sets of parallel or radiating feathery crystals. Individual augite crystals are much less than $0.01 \mathrm{~mm}$ wide and typically about $0.1 \mathrm{~mm}$ long. In many places they occur enclosed in plagioclase and alkali(?), feldspar. An opaque mineral, tentatively identified as magnetite, occurs as 0.05 to $0.01 \mathrm{~mm}$ wide equant crystals that make up 2 to $3 \%$ of the rock. Apatite occurs as minute elongate crystals enclosed in all other minerals and an apatite microphenocryst was noted in one thin section.

A chemical analysis and norm of the volcanic rock from Site 179 (Core 13) are shown in Table 5a. Both the original analysis and an analysis recalculated water-free to $100 \%$ are shown. The norm was calculated using both the reported $\mathrm{Fe}_{2} \mathrm{O}_{3} / \mathrm{FeO}$ ratio of $6.1 / 2.9$ and an arbitrary ratio of $1 / 9$. The high ferric iron content undoubtedly reflects alteration of the rock. Depending on the $\mathrm{Fe}_{2} \mathrm{O}_{3} / \mathrm{FeO}$ ratio, the rock is quartz normative or slightly olivine normative. The rock has a high silica and alkali content. Its chemical characteristics are similar to rocks dredged from the nearby Giacomini Seamount (Forbes et al., 1969) and from Kodiak Seamount (Forbes and Hoskins, 1969). In all of its major oxides the Site 179 volcanic rock is intermediate in composition between an alkalic andesine basalt (hawaiite) from Giacomini and trachyte from Kodiak. According to chemical parameters it is most similar to mugearite; Nockold's (1954) average mugearite is listed in the table for comparison. Most mugearites, however, contain more normative olivine and many contain normative nepheline. Although the silica content of the Site 179 mugearite is higher than Nockold's average mugearite, those from the Hawaiian Islands commonly contain this much or more silica (see MacDonald and Katsura, 1962, Fig. 2). The Site 179 mugearite differs from rocks of this same silica content on continental margins by a higher alkali content; some trachyandesites, however, are grossly similar in composition. The close pronimity of Giacomini Seamount and the similarity in composition of Site 179 mugearite to rocks from the seamount (and Kodiak) suggests that is may be derived from Giacomini.

Trace element abundances in the volcanic rock from Site 179 (Core 13) are shown in Table 5b. The trace element content differs greatly from the values reported by Engel et al. (1965) for average oceanic tholeiitic and alkalic basalts and from those of Taylor's (1969) average andesite. Particularly different are the low contents of $\mathrm{Co}, \mathrm{Cr}, \mathrm{Cu}$, $\mathrm{Ni}$, and $\mathrm{V}$ and high abundances of $\mathrm{Y}, \mathrm{Yb}$, and $\mathrm{Zr}$. In $\mathrm{Ba}, \mathrm{Co}$, $\mathrm{Cr}, \mathrm{Cu}, \mathrm{Ni}$, and $\mathrm{V}$, the rock is more similar to dacite or rhyolite as reported by Taylor (1969), but it differs markedly from them in $\mathrm{La}, \mathrm{Nb}, \mathrm{Y}, \mathrm{Yb}$, and Ar. The particularly high content of $\mathrm{Zr}$ and $\mathrm{Nb}$ in the volcanic rock from Site 173 suggests that it may be a product of strong fractional crystallization, inasmuch as $\mathrm{Zr}$ and $\mathrm{Nb}$ do not easily enter into lattice sites of minerals of basaltic rocks. Removal of olivine and pyroxene during fractional crystallization of basaltic magma might also have produced the low content of $\mathrm{Co}, \mathrm{Cr}$, and $\mathrm{Ni}$ which readily enter sites in these two minerals.

\section{REFERENCES}

Aumento, F., 1968. The Mid-Atlantic Ridge near $45^{\circ} \mathrm{N}$. II. Basalts from the area of Confederation Peak. Canadian J. Earth Sci. 5, 2. 
TABLE 5a

Chemical Analysis and Norm of Volcanic Rock from Site 179 (Sample 13C)

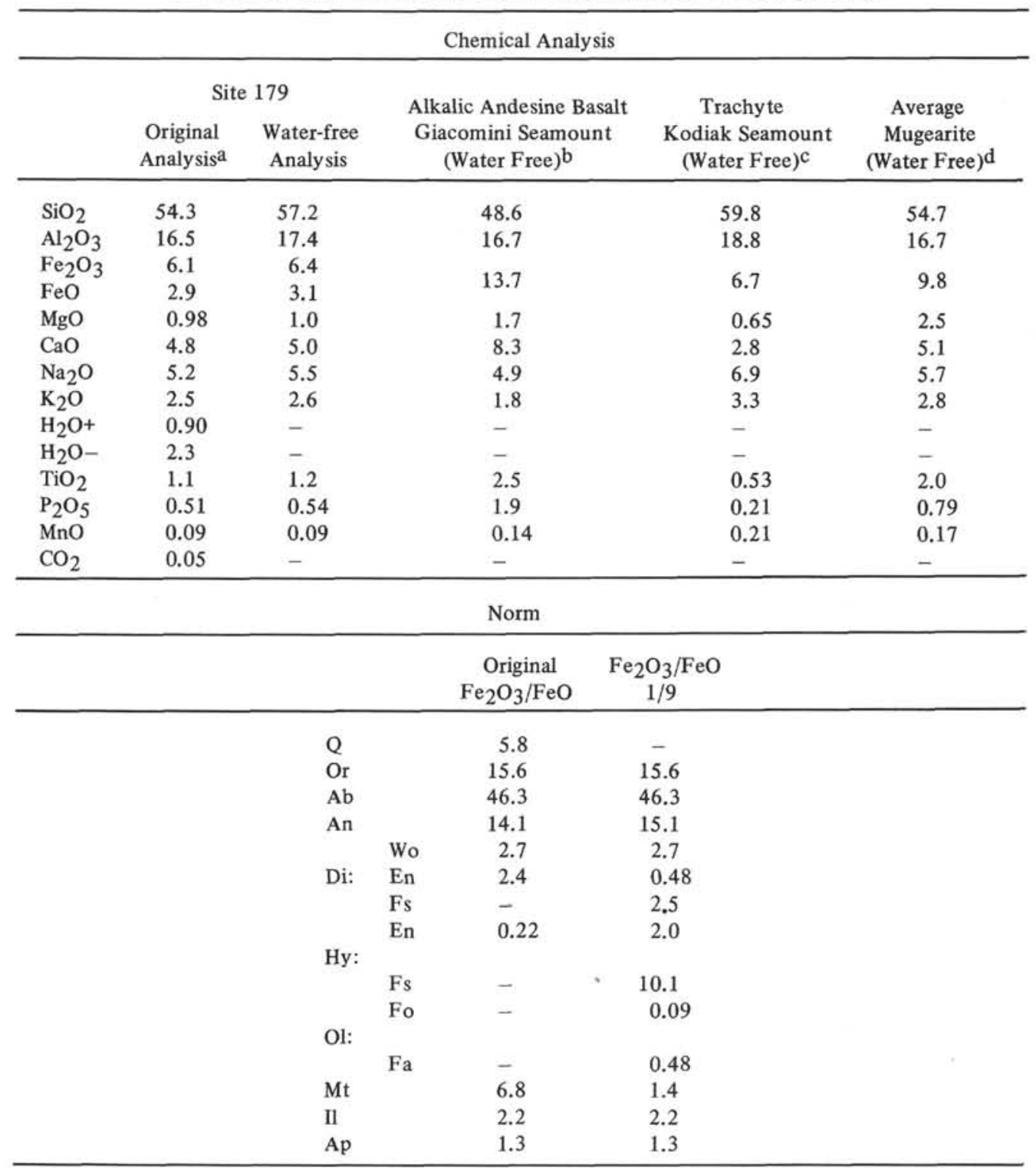

${ }^{a}$ Analytical methods used are those described in USGS Bulletin 1144A supplemented by atomic absorption,

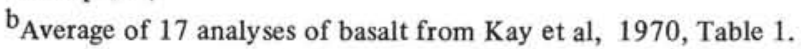

${ }^{C}$ From Forbes et al., 1969, Table 1, Col. 1.

${ }^{d}$ From Nockolds, 1954, Table, Col. 8.

Engel, A. E. J., Engel, C. G. and Havens, R. G., 1965 , Chemical characteristics of oceanic basalt and the upper mantle. Bull. Geol. Soc. Am. 76, 719.

Forbes, R. B. and Hoskin, C. M., 1969. Dredged trachyte and basalt from Kodiak Seamount and the adjacent Aleutian Trench, Alaska. Science. 166, 502.

Forbes, R. B. et al., 1969. Dredged basalt from Giacomini Seamount. Nature. 221 (5183), 849.

Gast, P. W., 1968. Trace element fractionation and the origin of tholeiitic and alkaline magma types. Geochim. Cosmochim. Acta. 32, 1057.

Hart, R., 1970. Chemical exchange between sea water and deep ocean basalts. Earth Planet. Sci. Letters. 9, 269.
Hotz, P. E. and Jackson, E. D., 1963. X-ray determination curve for olivines of composition Fo80-95 from stratiform and alpine-type peridolites. U.S. Geol. Survey Prof. Paper 450-E, 101.

Kay, R., Hubbard, N. J. and Gast, P. W., 1970. Chemical characteristics of oceanic ridge volcanic rocks. J. Geophys. Res. 75 (8), 1585.

MacDonald, G. A. and Katsura, T., 1962. Relationship of petrographic suites in Hawaii. In Crust of the Pacific Basin. Geophys. Monogr. 6. 187.

Nockolds, S. R., 1954. Average chemical composition of some igneous rocks. Bull. Geol. Soc. Am. 65, 1007. 
TABLE 5b

Trace Element Abundances (Spectrographic Analy sis; ppm) of Volcanic Rock from Site 179 (Core 13) and the Average Composition of Oceanic Tholeiitic

Basalt and Alkalic Basalt of Engel et al., (1965)

\begin{tabular}{lrrrr}
\hline & $\begin{array}{r}\text { Site } \\
179 a\end{array}$ & $\begin{array}{c}\text { Average Oceanic } \\
\text { Tholeiitic Basalt }\end{array}$ & $\begin{array}{c}\text { Average } \\
\text { Alkalic Basalt b }\end{array}$ & $\begin{array}{c}\text { Average } \\
\text { Andesitec }\end{array}$ \\
\hline $\mathrm{Ba}$ & 420 & 14 & 498 & 270 \\
$\mathrm{Co}$ & 6 & 32 & 25 & 24 \\
$\mathrm{Cr}$ & $\mathrm{N} 2$ & 297 & 67 & 56 \\
$\mathrm{Cu}$ & 10 & 77 & 36 & 54 \\
$\mathrm{Ga}$ & 33 & 17 & 22 & 16 \\
$\mathrm{La}$ & 110 & $<80$ & 90 & 12 \\
$\mathrm{Nb}$ & 88 & $<30$ & 72 & 4 \\
$\mathrm{Ni}$ & $\mathrm{N} 2$ & 97 & 51 & 18 \\
$\mathrm{Sc}$ & 36 & 61 & 26 & 30 \\
$\mathrm{Sr}$ & 680 & 130 & 815 & 385 \\
$\mathrm{~V}$ & $\mathrm{~N} 4$ & 292 & 252 & 175 \\
$\mathrm{Y}$ & 96 & 43 & 54 & 21 \\
$\mathrm{Yb}$ & 10 & 5 & 4 & 2 \\
$\mathrm{Zr}$ & 950 & 95 & 333 & 110 \\
\hline
\end{tabular}

${ }^{\text {a Site }} 179$ analysis results are reported to two significant figures and have an overall accuracy of $+15 \%$ except that they are less accurate near the limits of detection where only one digit is intended. $\mathrm{N}=$ Not detected at value shown.

${ }^{b}$ Engel et al., 1965, Table 2.

'Taylor, 1969, Tables 1-6.
Peck, D. L. et al., 1964. Geology of the central and northern parts of the western Cascade Ranges in Oregon. U.S. Geol. Surv. Prof. Paper 449. 56 p.

Prinz, M., 1967. Geochemistry of basaltic rocks: trace elements. In Basalts: the Poldervaart treatise on rocks of basaltic composition, V. 1. Hess, H. H., Poldervaart, A. (Eds.). Interscience, New York, 271.

Taylor, S. R., 1969. Trace element chemistry of andesite and associated calc-alkaline rocks. In Proceedings of the Andesite Conference, McBirney, A. R. (ed.). Oregon Dept. Geol. Min. Indust. Bull. 65. 43.

Williams, H., 1942. The geology of Crater Lake National Park, Oregon with a reconnaissance of the Cascade Range southwest to Mount Shasta. Carnegie Inst. Washington, Publ. 540. 162 p.

Yoder, H. S., Jr., and Sahama, Th. G., 1957. Olivine X-ray determinative curve. Am. Mineralogist, 42, 475. 